\title{
COMMUNICATING CUSTOMER VALUE BASED ON MODERN TECHNOLOGIES
}

\author{
Czarniewski, S.
}

The article presents the idea of gaining a position of competitive advantage by companies operating in the knowledgebased economy and in the age of modern technology. The rate of change in companies' environments forces organizations to react quickly to clients' needs. In recent years, there has been an observed systematic increase in the importance of communicating customer value in Poland. This paper shows changes (trends) in the system of market communication in the age of modern technology and changes in the economy. The author presents the mechanisms and effects of communication in age new technology in Poland. Modern technologies enable the collection, storage and transmission of information. Reflections contained in the paper do not have definite characteristics and should be treated as an opinion in the discussion.

JEL Classification: M31, M37.

Keywords: online advertising; marketing communication; new technologies.

\section{Introduction}

The traditional way of communicating with customers no longer works the way it did in the 1980's and 1990's. During this time, it was enough to make the company visible. Meanwhile, the market has become more competitive, consumer expectations have changed, and new technologies have entered the field of communication. There has been a natural tendency for society to divide into increasingly diverse consumer groups with well-specified preferences and expectations, and there is a greater demand for offers tailored specifically to their needs. In this situation, techniques and tools used in direct communication have become much more effective.

The process of communicating customer value not only provides buyers with awareness of what products and services they can buy, but also the benefits of purchasing them. The communication process aims to create and strengthen attitudes among buyers, leading to a favorable reception of products / services as well as a change of attitude from neutral to positive - creative.

The above objectives correspond to the research hypotheses:

1. Changes in today's business environment imply the need for effective action - on the part of the company - in terms of communicating customer value.
2. It is necessary to use - by entities operating on the market - modern marketing communications media on a larger scale. Multimedia marketing campaigns are usually more effective than campaigns run in only one medium.

\section{Characteristics of the Internet Communications Market}

The online advertising market is growing the fastest of all markets. Currently, according to estimates, every third inhabitant on the planet has access to the Internet. About $58 \%$ of Europeans use the Internet (http://Internetworldstats.com stats4.htm [accessed: 10. 06.2012].

In Poland, year by year, systematically, there is an increasing number of households that have access to the Internet. In 2010, Poland, with an index of 63\%, was in the middle of the list of European countries in terms of number of households with access to the Internet. The largest percentage of the population with Internet access in Europe is in the Netherlands - 93\%.

The age structure of Internet users and frequency of use of the Internet has not, in recent years, seen major changes. Most Internet users in Poland are young people, of which the largest percentage of people are between the ages of 15 to 24 years. A small percentage 
Figure 1 The age structure of Internet users in Poland in 2013

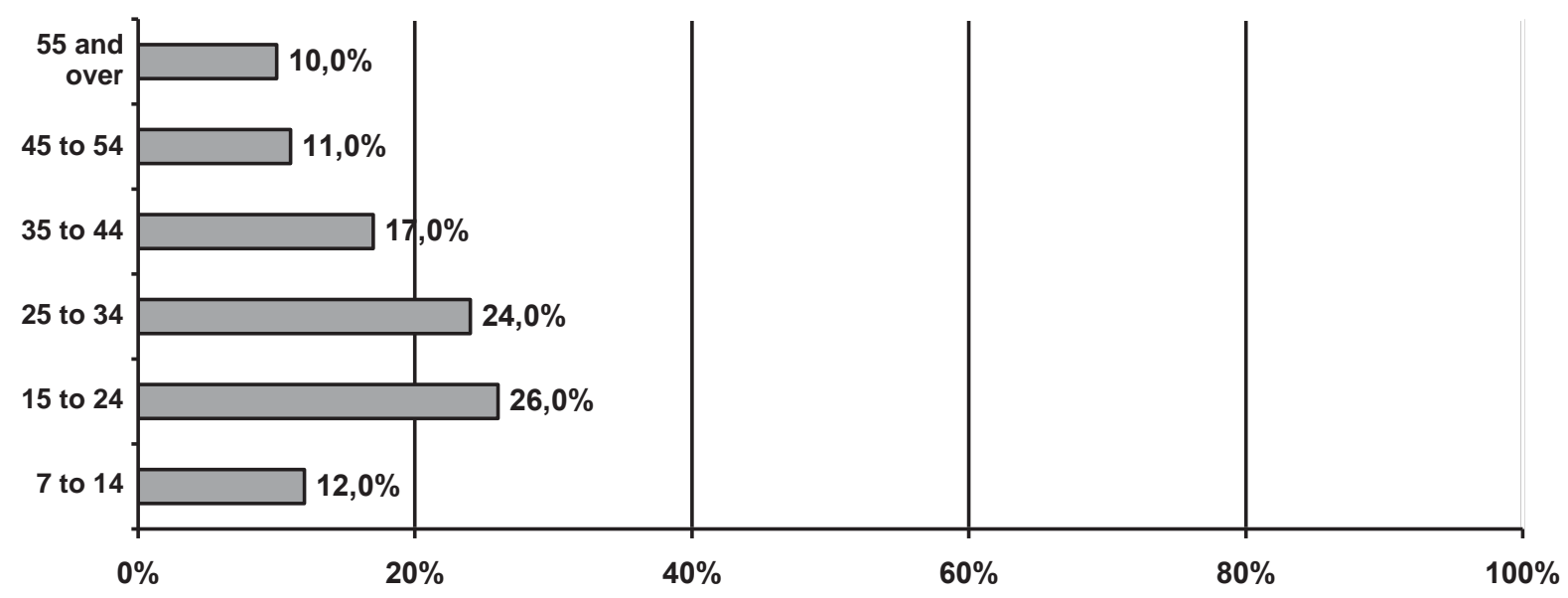

Source: Megapanel/PBI, December 2013, (accessed May 07, 2014), [available at http://gemius.pl/pl/aktualnosci].

Figure 2 Frequency of Internet use by Polish Internet users in 2013

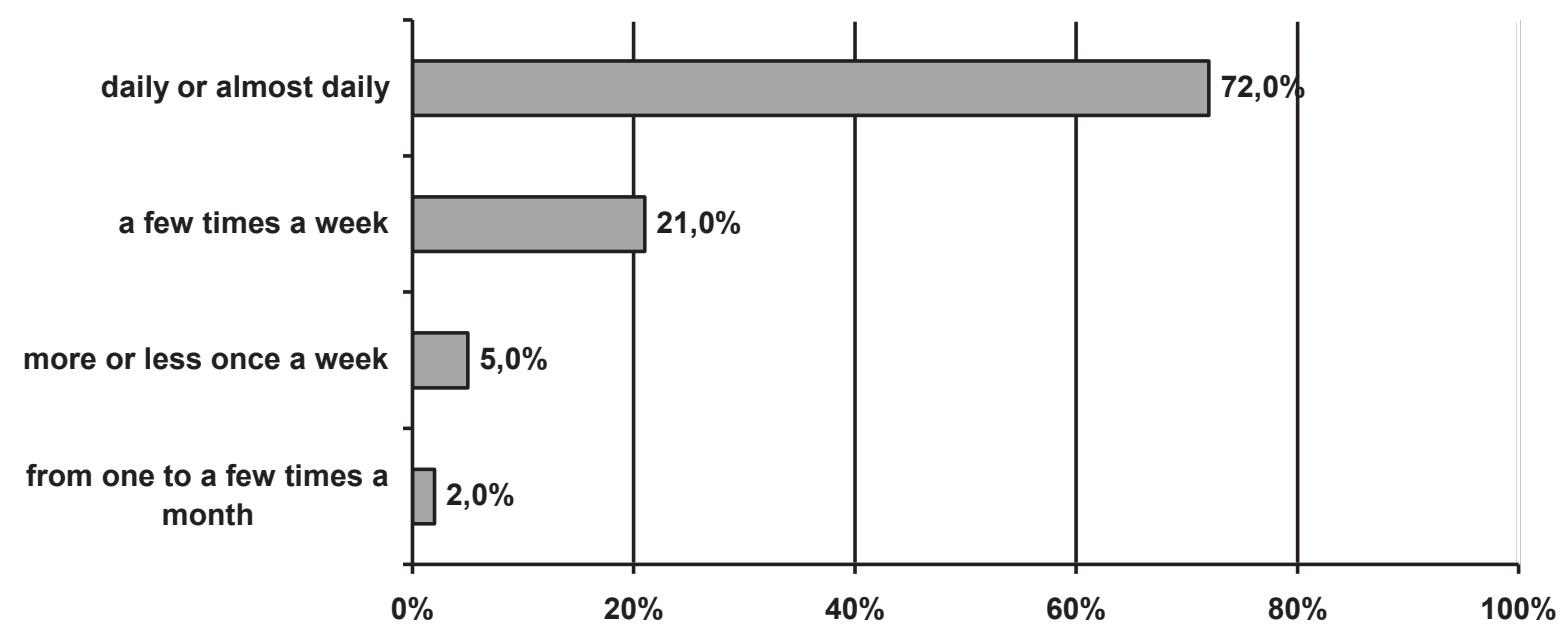

Source: Megapanel/PBI, December 2013, (accessed May 08, 2014), [available at http://gemius.pl/pl/aktualnosci].

of Internet users are people over 55 years of age (Figure 1.) The age structure of Internet users has remained at a similar level for the last several years.

The frequency of Internet use in recent years is comparable. Seventy two percent of Polish Internet users use it every day or almost every day (Figure 2). Only five percent of Internet users use it less than once a week. Internet users search for a variety of information and news about products, services, and companies. The most sought-after data is on mobile network operators (76\%), cosmetics (41\%) and food products (41\%). Users search for information concerning the quality of products, prices, content, and application. In the case of cosmetics, $32 \%$ of respondents said that the knowledge gained about the product through the Internet definitely helped them make the decision to purchase, while $51 \%$ said that the obtained information rather helped in the decision (Świerczewska, Wiśniewska, 2011). These numbers show the strength the Internet has on impacting consumers looking for information about a product. Over the last several years, the Internet has become the main source of information about products, and is the primary source of information when making purchasing decisions. 
Figure 3 The most popular Internet portals in Poland in 2013

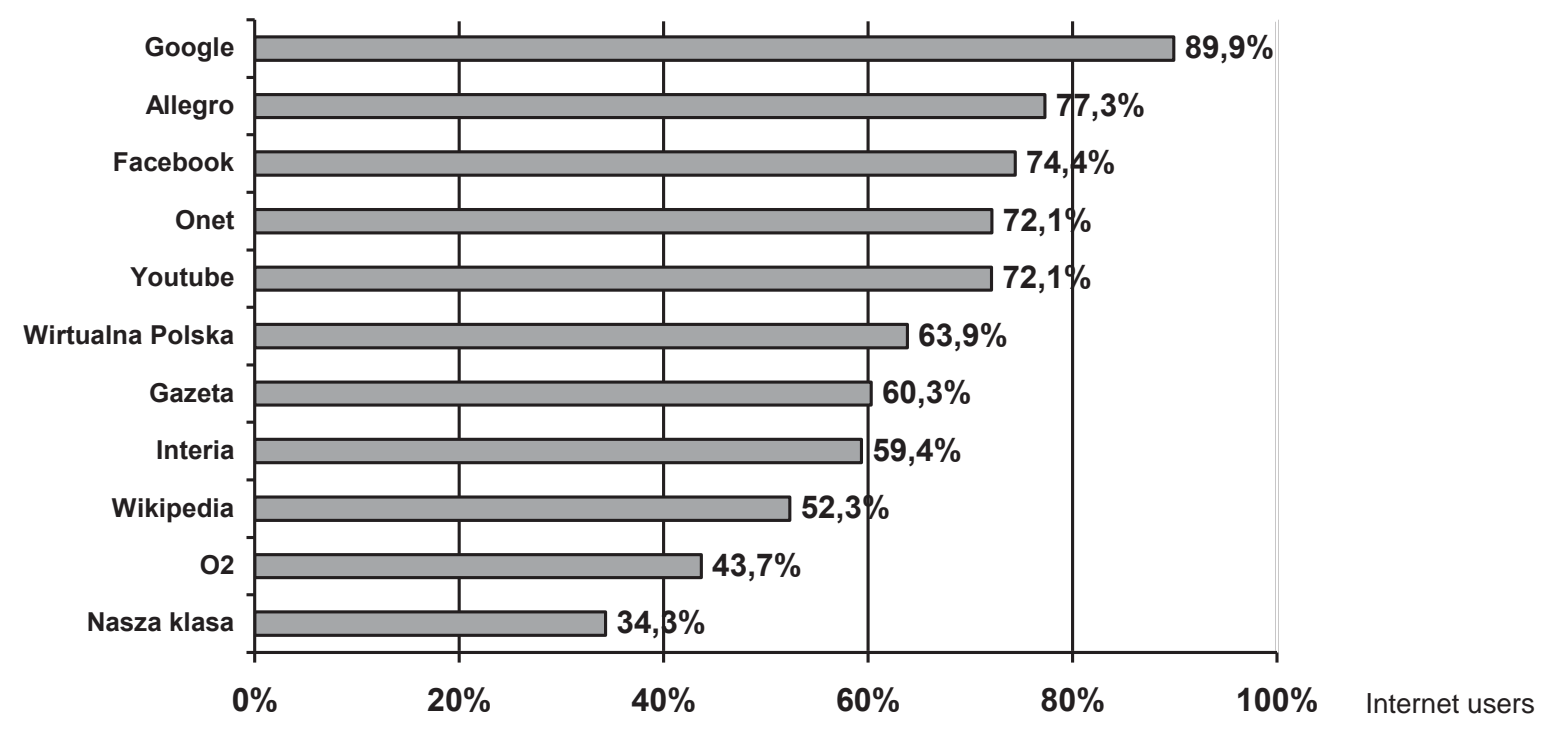

Source: Study „Megapanel / PBI“ conducted among Internet users in November 2013.

The Internet is constantly evolving, and the number of users and number of sites is growing. Figure 3 shows the most popular web portals in Poland in 2013. During this period, the most popular sites were Google.pl, Allegro. pl and Facebook.pl. It should be noted that 18 of the top 20 most popular websites in Poland in 2013 reported an increase in the number of visitors. The most popular were still the Google.pl group (over 19 million visits),
Allegro Group (over 16 million visits), Facebook.com (over 16 million visits), Onet.pl group (over 14 million visits), Youtube.pl group (over 15 million visits).

Poland is at the forefront of European countries which, in recent years, recorded the largest increase in spending on online advertising. According to a survey conducted by Pricewaterhouse Coopers and IAB Poland, gross expenditure on Internet advertising in 2011 amounted

Figure 4 The amount of spending on online advertising in Poland in 2007-2012

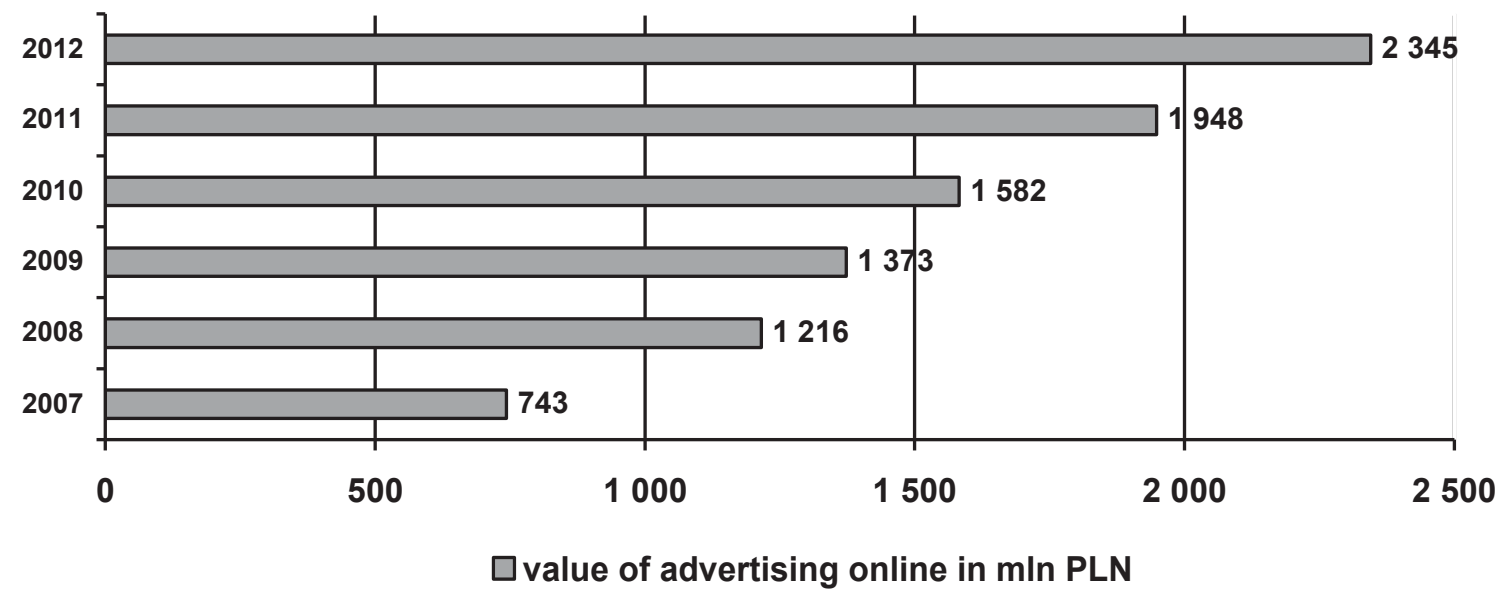

Source: Own research based on the Report of the IAB AdEx $2011 \mathrm{FY}$, (accessed April 11, 2013), [available at http://www. iabpolska.pl/images/stories/komunikaty/2013_03_08_IAB_AdEx_2010FY_raport_dla_medi\%C3\%B3w.pdf]. 
to 1,948 billion PLN (Figure 4.). Expenditures increased by $12.3 \%$ compared to the previous year. The economic crisis has not touched the online advertising industry, as happened in the case of other media. Companies which had previously started to cut back on advertising on traditional media such as newspapers, are investing their capital into online advertising. Experts predict further increases in spending on online advertising. Spending won't be as great as in previous years, because the Polish advertising market is maturing.

Second place, in terms of popularity of Internet advertising, was achieved by SEM Advertising, which consists of two options: PPC - pay per click paid sponsored links campaigns, and SEO - search engine optimization. The goal of SEM is to achieve the best position for a given website in the search results presented for the search engine user. In 2010, SEM Advertising accounted for $30 \%$ of all advertising spending on the Internet. Compared with 2009, there has been increased interest in SEM Advertising - from 26\% to 30\% (Drzewosowski, Kolenda, 2010). Published classifieds on the Internet were in third place. In 2010, they represented $17 \%$ of all online advertising expenditure. The popularity of online classifieds increased by $2 \%$ compared with 2009.

\section{Marketing communication in age modern technologies}

The Internet is undoubtedly the youngest market communication medium. Communication on the Internet is becoming more and more popular among both broadcasters who have more opportunity to present their products as well as among recipients. It is also the fastest growing medium, which means that it may soon supplant many traditional, standard communication channels. The Internet enables consumers to buy the product immediately after hearing about the offer on the Web. Because of its features, through proper use, the Internet can be an attractive medium of communication; through the use of video, sound, graphics and computer animation, it provides virtually unlimited creative possibilities.

Through the use of a web page, the following marketing objectives can be achieved:

- shaping the image and brand of the organization as modern and innovative,

- providing and disseminating information about the company, products, and people,

- acquiring new clients, networking,

- building relationships, carrying out dialogues, enabling interactions,

- integrating users, preparing a platform for the exchange of information (Mazurek, 2008).
Communication via modern technology has the aim of strengthening a positive image of the company and its products in the minds of consumers. This type of communication has a greater impact and attracts more attention, and thus increases the efficiency of communication (Howard, Gengler, 2001).

Modern technologies encourage action on the part of the consumer, which is usually to place an order, since the Internet simplifies the placing of orders and making payments - the entire transaction can be done through a web page or e-mail.

The aim of interactive communication is to increase the effectiveness of other elements of the marketing mix, i.e. product, price and distribution, in a competitive market. A company using modern technology is considered to be more modern and innovative in comparison to the competition.

There are product websites which focus mainly on presenting the product and trademark directed to individual customers. The purpose of these websites is to build an online community centered around the product and create an atmosphere of uniqueness of their brand, and thus loyalty to the product.

It should be noted that companies are increasingly using blogs appropriately constructed to interact with customers. A blog is a tool that can help, but also harm, the image of the organization. If used correctly, it increases the openness of the company and its employees to their surroundings, builds its image as an expert in the industry, enables more flexible and rapid flow of information and is an effective tool for internal communication. If the author's intentions are dishonest or they allow themselves to be manipulated, it may lead to the disclosure of confidential information, business plans, strategies, etc. on the blog. Placing false or unverified information on the blog by an employee may even cause a decline in stock prices, especially if the source of the astounding news is a member of the management team of the company. Then it is natural that the company will attempt to discredit the author in order to defend their image (Borkowski, 2007).

It should be mentioned that an intranet enables efficient communication and organization of work within the company, allowing for the dissemination of various types of messages related to the ongoing activities of different units, circulation of decisions made by senior management of the company, and communication between employees at all levels of the organization. An intranet, moving the process of internal communication to the web, allows for significant improvements and savings and, consequently, is an effective way of increasing the efficiency of the entire organization. 
Table 1 The most important benefits provided by some social networking platforms aimed at Polish-speaking Internet users

\begin{tabular}{|c|c|c|}
\hline Platform Name & Core Offer & $\begin{array}{l}\text { Year established and Web } \\
\text { address }\end{array}$ \\
\hline GoldenLine & $\begin{array}{l}\text { Connecting a community focused on career development and } \\
\text { professional life, enabling the exchange of professional experiences }\end{array}$ & $\begin{array}{l}2005 \\
\text { goldenline.pl }\end{array}$ \\
\hline Nasza klasa & A chance to renew acquaintances with old friends & $\begin{array}{l}2006 \\
\text { nk.pl }\end{array}$ \\
\hline Gastronauci & $\begin{array}{l}\text { Opportunity to exchange opinions about restaurants with other food } \\
\text { lovers }\end{array}$ & $\begin{array}{l}2007 \\
\text { gastronauci.pl }\end{array}$ \\
\hline Kolumber & $\begin{array}{l}\text { Sharing information about traveling, exchange of experiences regarding } \\
\text { tourist destinations, exchanging recommendations on providers in the } \\
\text { tourism market }\end{array}$ & $\begin{array}{l}2008 \\
\text { kolumber.pl }\end{array}$ \\
\hline $\begin{array}{l}\text { Pluru - Choices } \\
\text { made daily }\end{array}$ & $\begin{array}{l}\text { The opportunity to test the popularity of an idea by comparing } \\
\text { a personal stance on public issues with the opinion of any other } \\
\text { arbitrarily selected person }\end{array}$ & $\begin{array}{l}2009 \\
\text { pluru.pl }\end{array}$ \\
\hline Bobas & $\begin{array}{l}\text { Opportunity to exchange information and share experiences with } \\
\text { parents of young children }\end{array}$ & $\begin{array}{c}2009 \\
\text { ebobas.pl }\end{array}$ \\
\hline
\end{tabular}

Source: own research based on M. Jaśniok, Portale społecznościowe, in: Narzędzia i techniki komunikacji marketingowej XXI wieku, edited by K. Sliwinska, M. Pacut, Wolters Kluwer Publishing, Warsaw 2011, p 50.

The Internet, as a worldwide computer network, allows members of the virtual community to connect with each other. Communication developed with the ability to send emails from web pages and participate in discussion groups, allowing members of the virtual community to form a large number of diverse ties.

The communication needs of Internet users are virtually unlimited, and social networking sites are also extremely varied, with the intention of satisfying user needs. More than $61 \%$ of users visit social networking sites to maintain friendships, $41 \%$ out of curiosity, and $31 \%$ as a way to spend their free time. Only $22 \%$ of users visit social networking sites to make new friends, and just $18 \%$ to discuss topics of interest to them (accessed January 10, 2010) [Available at http://biznes.gazetaprawna.pl/ artykuły/340708].

Table 1 presents some of the platforms operating on the Polish market, together with the basic aims of their operations and the benefits the platform provides for its users, which comprises its core offer.

Research carried out on the U.S. market in 2009 shows that Internet users who use social networking sites do not treat communication in a virtual environment as a substitute for interpersonal communication performed in the real world. On the contrary, the results show that active Internet users engage more often in social life than those who do not use the Internet. Moreover, they are more open-minded, tolerant, and have an easier time making new friends than people who are skeptical about any technological innovations and the Internet itself (Report, 2010). The psychological characteristics of this group of consumers were very quickly noticed by some of the companies operating in the market.

Electronic services in the government play a very important role in the digital revolution which is now taking place, as well as in the rapid development of technology, which is why the computerization of government is an extremely important element for developing the information society in Poland (Budziewicz-Gruźlecka, 2008).

An important issue in Poland is the availability of new tools and communication technologies in public administration. Administration services use the Internet to create new channels of communication between public offices and citizens, support existing channels, improve collaboration, and create a pleasant atmosphere (Dąbrowska, Janoś-Kresło, 2009). The conversion of public offices to e-offices open 24 hours a day, seven days a week, has resulted in bringing natural and legal persons a greater variety of ways to communicate with the public office and provide information, and overall improve quality. The change is also associated with saving time, as well as providing a high level of flexibility both in the choice of location and time of day for handling official matters. The result has been an improvement of the services provided, and thus an increase in the satisfaction of customers (Report, 2004).

For the needs of research on the development of e-government, twenty basic public service categories 
were denoted; twelve of them addressed citizens and eight, entrepreneurs. From the analysis of the current state of those twenty basic public services which should be fully available on-line, as recommended by the European Commission, the number in Poland was half of the EU average (in 2007 the rate was $25 \%$ while the EU average 59\%) (Grodzka, 2007). Only four have reached the level of transactional services which allow full interaction with the authorities through the use of electronic channels.

Communicating customer value is increasingly based on modern direct marketing. The electronic version of direct mail order marketing seems to have great prospects ahead, and this is mainly due to the continual rapid growth (and the emergence of new) channels of direct communication. Newsletters, which are already known on the market, are slowly being replaced with RSS feeds (Andrusiewicz, 2007); promotional e-mails are complemented by messages sent via online instant messaging. It should also be noted that with the technological development of mobile telephones, mobile channels of communication are also developing (SMS, MMS, and most recently, information sent via bluetooth).

The development of Internet transactions goes hand in hand with verifying clients (a basic query of credibility). B. Dobiega-Korona notes that the effective use of the Internet to develop value depends on creating a balance between the collection of personal information from consumers and guaranteeing them their desired level of privacy protection and control over personal information (Dobiegała-Korona, 2007). New services on the Internet, i.e. online lending platforms (social lending, C2C), which are also present in Poland (Masiukiewicz, 2007), will require information about clients from organizers and participants of the system in order to reduce risk.

\section{New Requirements for Communication through the Internet}

Companies are continually taking steps in order to enhance the effectiveness and efficiency of modern means of communication. In order for a website to serve as an effective market communication channel, it needs to be attractive enough for the recipient to look for it themselves.

A study called Megapanel / PBI collects information on all commercial sites on the Polish Internet. It allows for the creation of a detailed profile of the users of each site; what's more -- it gives the opportunity to plan campaigns based on indicators used in other media. People involved in planning campaigns have such indicators as reach and frequency available to them. This approach to planning can affect the measurement of the effectiveness of activities performed on the Internet. Not all clients will measure the rate of conversion, because a particular action is not expected from all Internet users.

Many organizations are involved in studying the Internet and the effectiveness of Internet websites. The leader in terms of coverage is the site Google, which is visited by more than $92 \%$ of Polish Internet users every month. The next sites (grouped and ungrouped) ranked in terms of monthly reach are: Onet.pl group (72\%), Nasza-klasa.pl (69\%), Wirtualna Polska group (62\%), Allegro.pl group (62\%) Interia.pl group (59\%), Gazeta.pl group (57\%), O2.pl group (55\%), YouTube.com (55\%), Wikipedia group (43\%) (Megapanel, 2009).

With the increase in bandwidth and connectivity, transmitted content will gain a more multimedia character, there will be much more television coverage, the image will be clearer, more accurate, and larger. Internet advertising will change in character: from informational to emotional, often entertaining, strongly influential on the emotions of the recipient (Perry, 2001).

B. Kaznowski emphasizes the role of interactivity of websites, which is part of the possibilities and nature of the Internet (Kaznowski, 2008). Interactivity is a feature that is considered the most important difference between the Internet and traditional communication channels. By utilizing various technical possibilities, users (potential consumers) will cease to be passive recipients and become partners in dialogue.

As noted by A. Burgiel, power belongs to those who have information, have access to unique data, specific knowledge, and who have it faster than others (Burgiel, 2006). The Internet, as one of the greatest tools for conveying information, has become an effective instrument for those who want to gain power, including those companies that wish to reach the consumer through the Internet. The rapid development of the web has actually caused the opposite - the Internet has become both a protective shield and a source of strength, and even power, for many isolated, individual consumers.

According to L. Weber, the role of Marketing Specialist (marketer) has significantly changed as a result of social media, from a position of one who broadcasted messages and sent news (market information) to consumers, to a position of an aggregator who gathers new ideas, research and opinions, collaborates with clients, and builds and participates in an online community. Collaborating with clients means creating an open environment in which users can share their knowledge. 
The aggregator, who the marketer has become, takes care of the needs of the whole group, and does not forget about individuals (Weber, 2007).

It should be noted that the individual Polish client is still limited by a number of factors which interfere with the free use of modern information technologies. The multitude of conditions which characterize the situation of the client is quite specific and relates to Poland and other countries with a less developed ICTInformation Communication Technology sector. Here we can talk about the complex telecommunications environment of the Polish customer (Gutowski, 2008). Their selection of a given telecommunication service is characterized by a much lesser degree of freedom than customers residing in more developed countries (where the main deciding factors are price and customer preferences).

\section{Conclusion}

Polish marketing, due to the crisis of the past couple of years, has undergone major professionalization. Only the strongest advertising agencies, in terms of economics, were able to remain on the market, and they are continuously developing. The increase in spending on marketing communication results from the focus on sales results, and here the best suited instruments are direct and interactive marketing tools.

Communicating customer value is increasingly based on modern direct marketing. The electronic version of direct mail order marketing seems to have great prospects ahead, and this is mainly due to the continual rapid growth channels of direct communication. It should also be noted that with the technological development of mobile telephones, mobile channels of communication are also developing (SMS, MMS, and most recently, information sent via bluetooth).

Managers very quickly began to see the advantages of communication through modern technology, which resulted in a gradual development of company websites, which served as their Internet business cards. With time, more and more services were developed and offered more detailed information about the company and their products (services), sales network, etc.

The Internet enables consumers to buy the product (service) immediately after hearing about the offer on the web. Because of its features, through proper use, the Internet can be an attractive medium of communication; through the use of video, sound, graphics and computer animation, it provides virtually unlimited creative possibilities.

\section{References}

Andrusiewicz, P. (2007). Internet na tle mediów tradycyjnych, in Stownik wiedzy o mediach, ed. Chudziński, E., Warsaw: PWN.

Borkowski, T. (2007). Blog jako narzędzie marketing. Gazeta Bankowa, 49: 45-47.

Budziewicz-Gruźlecka, A. (2008). Stan rozwoju e-usług administracji publicznej w polskim społeczeństwie informacyjnym. Zeszyty Naukowe Uniwersytetu Szczecińskiego, 27: 187-199

Burgiel, A. (2006). Wykorzystanie Internetu w procesach decyzyjnych konsumentów, in Konsumencki proces decyzyjny i jego determinanty, ed. Kieżel, E., Katowice: University of Economics in Katowice Publishing.

Dąbrowska, A., Janoś-Kresło, M., Wódkowski, A. (2009). E-ustugi a społeczeństwo informacyjne. Warsaw: Difin Publishing.

Dobiegała-Korona, B. (2007). Zaufanie klienta. Kwartalnik Nauk o Przedsiębiorstwie, 2: 23.

Drzewosowski, M., Kolenda P. (2010). Narzędzia e-marketingu. Wydatki na reklamę online, (accessed June 12, 2012), [available at http://www.iabpolska.pl/ images/stories/raporty/Raport_strategiczny_IAB_Polska_ INTERNET_2010.pdf].

Grodzka, D. (2007). E-administracja w Polsce, Infos, (accessed January 10, 2010), [available at http:// parl.sejm.gov.pl/WydBAS.nsf/0/5 B3DCD2 263623 C69C125730E003F93CA/\$file/infos_018.pdf].

Gutowski, P. (2008). Model otoczenia klienta indywidualnego na rynku usług telekomunikacyj-nych w Polsce. Zeszyty Naukowe Uniwersytetu Szczecińskiego, 519: 410.

Howard, D. L., Gengler, C. (2001). Emotional Contagion Effects on Product Attitudes. Journal of Consumer, 28 (September): 57-58.

Kaznowski, D. (2008). Nowy marketing. Warsaw: Wydawnictwo VPF Communications.

Masiukiewicz, P. (2007). Marketing $w$ enklawach finansowych. Warsaw: Difin Publishing.

Mazurek, G. (2008). Promocja w Internecie. Narzędzia, zarzadzanie, praktyka. Gdańsk: Center for Consultancy and Training Resources.

Megapanel (2009). Research results of Megapanel PBI/for August 2009, (accessed December 15, 2009), [available at http://pliki.gemius.pl/Komunikaty/2009/Megapanel/ Wyniki_Megapanel_PBI_Gemius_sierpien_2009.doc]. 
Perry, S. D. (2001). Commercial humor enhancement of program enjoyment: Gender and program appeal as mitigating factors, "Mass Communication and Society", 4: 104-105.

Report (2010). Report from the Institute of MillwardBrown SMG/KRC commissioned by D-Link, (accessed January 10, 2010), [available

at http://biznes.gazetaprawna.pl/artykuły/340708].

Świerczewska, H., Wiśniewska A. (2011). Konsumenci online, in Raport Strategiczny IAB Polska Internet 2010, Media \& Marketing Polska, Special Edition May 2011: 20-21.
Weber, L. (2007). Marketing to the Social Web: New Digital Customer Communities Build Your Business, New Jersey: John Wiley \& Sons.

\section{Author}

Dr. Sławomir Czarniewski

University of Finance and Management in Bialystok

UI. Ciepła 40

15-472 Białystok, Poland s.czarniewski@wp.pl 